\title{
Chronic diarrhoea after radiotherapy for gynaecological cancer: occurrence and aetiology
}

\author{
Å Danielsson, H Nyhlin, H Persson, U Stendahl, R Stenling, O Suhr
}

\begin{abstract}
The occurrence of chronic diarrhoea was evaluated in 173 consecutive patients previously treated with radiation for gynaecological cancer. A survey of gastrointestinal symptoms showed a high frequency of diarrhoea; $13 \%$ of the patients had 21 or more bowel movements a week and $3 \%$ had 28 or more. Significantly more patients who had a cholecystectomy were in the group with diarrhoea $\left(\chi^{2}=6.26 ; \mathrm{p}<0.02\right)$. Twenty patients with chronic or intermittent diarrhoea were subject to extended gastrointestinal investigation. Bile acid malabsorption was evaluated by the ${ }^{75}$ Selenahomocholic acid-taurine test (SeHCAT). Bile acid malabsorption was found in $13(65 \%)$ of the 20 patients further investigated, of whom seven had extremely low whole body retention values, which is consistent with severe malabsorption. The results suggest that bile acid malabsorption is a common cause of diarrhoea after radiation treatment for gynaecological cancer. Bacterial contamination was diagnosed in nine patients $(45 \%)$ by the $\left[{ }^{14} \mathrm{C}\right]-\mathrm{D}$-xylose breath test or by the cholyl$\left[{ }^{14} \mathrm{C}\right]$-glycine breath test in combination with a normal test for bile acid malabsorption. All patients with vitamin B-12 deficiency, who were tested for bile acid malabsorption, had low retention times for the SeHCAT $(p=0.05)$. A significant decline in the frequency of diarrhoea was found after treatment with antibiotics or bile acid sequestrants, or both, in combination with a reduced fat diet.
\end{abstract}

Diarrhoea is an acknowledged symptom during and immediately after radiation treatment for gynaecological cancer. Enteropathy can be expected to occur in up to $15 \%$ of patients during or after receiving a dose of $40-80 \mathrm{~Gy} .^{\prime}$ As the small intestine has the highest cell turnover rate, it is the most vulnerable. Such acute radiation induced intestinal damage, however, has none of the specific features of chronic radiation enteropathy, as described by Warren and Friedman. ${ }^{2}$ Symptoms of late radiation enteropathy generally appear after more than a year but can occur at any time during the lifetime of the patient. ${ }^{3}$ In these patients fat malabsorption is not uncommon and is probably due to a radiation enteropathy affecting the terminal ileum, thus causing bile acid malabsorption, which has been found by the measurement of faecal bile acids ${ }^{4}$ and the bile acid breath test. ${ }^{56}$ Moreover, intestinal motility may be altered in radiation enteropathy, and pseudo-obstruction has been described. ${ }^{7}$ It is therefore justified to suggest that diarrhoea after radiation treatment can also be caused by bacterial contamination of the small bowel which also causes an abnormal bile acid breath test.

In order to evaluate factors responsible for chronic diarrhoea in patients treated with radiotherapy for gynaecological cancer, we carried out a prospective study of bowel disturbance in outpatients attending the Department of Gynaecological Oncology, University Hospital of Umeå, more than two years after radiotherapy for gynaecological cancer. A subgroup of 20 patients with severe chronic diarrhoea were investigated for general malabsorption, bile acid malabsorption, and bacterial contamination of the small bowel. The effects of various treatments on the diarrhoea were also evaluated.

\section{Patients and methods}

\section{PATIENTS}

Altogether, 178 consecutive patients attending the outpatient clinic of the department during a six month period were included in a prospective study. Inclusion criteria were gynaecological cancer still healed two or more years after treatment including radiotherapy of the pelvis. Patients with intestinal resections or known gastrointestinal diseases were excluded.

Of the initial 178 patients, one had moved and was lost to follow up. Three patients who did not fulfill the inclusion criteria were excluded. One patient who was blind and unable to complete the questionnaire was also excluded. Thus 173 patients (97\%) were evaluated.

Of the 173 patients, 20 who complained of chronic or intermittent diarrhoea interfering with daily activities (mean age 45 years, range 29-72) accepted extended gastrointestinal investigations and were included in a prospective study of the pathogenesis and treatment of radiation induced diarrhoea. Patients with symptoms suggesting intestinal obstruction were excluded. One patient died during follow up from an intercurrent disease unrelated to the cancer (severe rheumatoid arthritis complicated by arteritis). No patients had received antibiotic treatment within one month of the investigations.

The study was approved by the local committee for ethics of Umeå University.

\section{RADIATION TREATMENT}

The patients had received radiotherapy 3 to 32 years before the investigation (mean 9 years). The treatment was given in the period 1953-83 and the mean age of the patients was 50 years (range 15-84 years). The 20 patients with severe chronic or intermittent diarrhoea who were extensively investigated had received radio-
Hospital, S-90185 Ume

Sweden

R Stenling

Correspondence to:

Accepted for publication 4 October 1990 
therapy 4 to 29 years before the investigation (mean 11 years). The patients had not been treated uniformly because of the different types of cancer and the changes in technology and equipment over the years. In general, patients with cervical carcinoma had received treatment according to a modified Stockholm method, with radium applications three times fortnightly followed one month later by external radiotherapy. ${ }^{89}$

External irradiation had been given with 220 $\mathrm{kV}$ roentgen, ${ }^{60} \mathrm{Co}$ photons or 4 to $20.9 \mathrm{MV}$ photons (linear acceleraters and microtron). Usually opposing pelvic fields $(16 \times 16 \mathrm{~cm})$ were used to a target dose of $40 \mathrm{~Gy}(2.5 \mathrm{~Gy} /$ day five days a week). All patients receiving radium applications according to the modified Stockholm method ${ }^{89}$ had external irradiation with central shielding $(9 \times 5 \mathrm{~cm}, 8 \mathrm{~cm}$ thick $)$.

Patients with ovarian malignancies had received a target dose of 40 Gy to the lower abdomen, below the umbilicus, followed one month later by one radium application. Generally these fields were slightly larger than those given to patients with cervical carcinoma. The mean fraction was smaller, 1.94 Gy (range $1 \cdot 85-2 \cdot 1)$.

There was no way to measure exactly the accumulated intestinal radiation dose. The dose to the rectum and bladder throughout the radium treatment was estimated from a measurement at the start of the treatment. The values listed in Table I are thus estimated doses.

\section{QUESTIONNAIRE}

A questionnaire was presented to all 173 patients for assessment of their bowel habit and gastrointestinal symptoms during the previous year. The patients were asked to estimate the proportion of bowel movements that were urgent or loose or watery. They thus scored their bowel habit subjectively from I to IV, where I indicated always normal and IV continuously abnormal bowel habit (by their own definition). Previous abdominal surgery unrelated to the malignant disease or radiation treatment was recorded, with special reference to cholecystectomy.

To avoid bias due to variation in bowel symptoms in different weeks, all patients also recorded their daily bowel habit with respect to number, consistency, and urgency during one specified week on a diary card. All patients complied. The diary card was later also used to evaluate the effect of various treatments.

\section{GASTROINTESTINAL INVESTIGATIONS}

The 20 patients who underwent extended gastrointestinal investigation for chronic or intermittent diarrhoea had the following examinations.

${ }^{75}$ Selenahomocholic acid-taurine test (SeHCAT)

After an overnight fast the patients received a capsule of $10 \mu \mathrm{Ci}(0.4 \mathrm{MBq})$ SeHCAT (Radiochemical Centre, Amersham, UK) with a glass of water. The measurements were carried out at 2 , 24,48 , and sometimes also at 72 hours in a low background laboratory with an uncollimated gammacamera as previously reported, ${ }^{10} 11$ and the biological half life of the isotope (WBR-50) was calculated. Values below 76 hours were regarded as abnormal ${ }^{11}$ and below 40 hours as severe bile acid malabsorption."

\section{$\left[{ }^{14} \mathrm{C}\right]$-bile acid breath test}

After an overnight fast the patients received $5 \mu \mathrm{Ci}(0.2 \mathrm{MBq})$ cholyl $\left[{ }^{14} \mathrm{C}\right]$-glycine (Radiochemical Centre, Amersham, UK) and 100 $\mu \mathrm{mol}$ cholyl glycine dissolved in $200 \mathrm{ml}$ of orange juice. The $\mathrm{CO}_{2}$ in breath was collected at hourly intervals in a trapping solution containing $2 \mathrm{mmol}$ hyamine hydroxide. The radioactivity was measured in a liquid scintillation counter (Beckman LS 2800). The cumulative radioactivity of the expired ${ }^{14} \mathrm{CO}_{2}$ was calculated for four and six hours respectively, after correction for endogenous $\mathrm{CO}_{2}$ production. ${ }^{1213}$ The results

TABLE I Diagnosis and treatment of 20 patients with radiation induced chronic diarrhoea subjected to extended gastrointestinal investigation

\begin{tabular}{|c|c|c|c|c|c|c|c|c|c|}
\hline \multirow[b]{2}{*}{$\begin{array}{l}\text { Patient } \\
\text { No }\end{array}$} & \multirow[b]{2}{*}{$\begin{array}{l}\text { Diagnosis, location, and } \\
\text { stage of cancer }\end{array}$} & \multirow[b]{2}{*}{$\begin{array}{l}\text { Surgical } \\
\text { treatment }\end{array}$} & \multicolumn{2}{|c|}{$\begin{array}{l}\text { External therapy: } \\
\text { Total dose }(G y)\end{array}$} & \multirow{2}{*}{$\begin{array}{l}\text { Radioactive } \\
\text { implant: } \\
\text { total loading } \\
\text { (mg radium } \\
\text { equivalent } \\
\text { hours) }\end{array}$} & \multicolumn{2}{|c|}{$\begin{array}{l}\text { Estimated total dose } \\
(G y)\end{array}$} & \multirow{2}{*}{$\begin{array}{l}\text { Intermission } \\
\text { during } \\
\text { treatment } \\
\text { (weeks) }\end{array}$} & \multirow{2}{*}{$\begin{array}{l}\text { Time from } \\
\text { treatment } \\
\text { (years) }\end{array}$} \\
\hline & & & $\begin{array}{l}\text { With } \\
\text { shield }\end{array}$ & $\begin{array}{l}\text { Without } \\
\text { shield }\end{array}$ & & Rectum & Bladder & & \\
\hline 1 & Cervical cancer, IB & - & 40 & - & 5480 & 41 & 41 & - & 6 \\
\hline 2 & Cervical cancer, IB & - & 40 & - & 6660 & 49 & 39 & - & 8 \\
\hline 3 & Cervical cancer, IB & - & 40 & - & 5660 & 37 & 38 & Split 3 & 6 \\
\hline 4 & Ovarian cancer, I & $\mathrm{HE}+\mathrm{SOE}$ & - & 40 & 1600 & 57 & 51 & Split 1 1/2 & 23 \\
\hline 5 & Cervical cancer, I & $\mathrm{HE}$ & - & 50 & 1400 & 60 & 56 & Split 4 & 21 \\
\hline 6 & Uterine cancer, I & $\mathrm{HE}$ & - & 40 & 1200 & 41 & 48 & Split 4 & 6 \\
\hline 7 & Uterine cancer, I & $\mathrm{HE}+\mathrm{SOE}$ & 40 & - & 5540 & 39 & 42 & - & 7 \\
\hline 8 & Ovarian cancer, IIA & $\mathrm{HE}+\mathrm{SOE}$ & - & 40 & 0 & 40 & 40 & Split 1 & 7 \\
\hline 9 & Cervical cancer, IIA & - & 40 & - & 7200 & 49 & 57 & - & 10 \\
\hline 10 & Cervical cancer, IIA & - & 40 & - & 6560 & 52 & 37 & - & 6 \\
\hline 11 & Cervical cancer, IB & - & 36 & - & 6460 & 43 & 46 & Discontinued & 18 \\
\hline 12 & Cervical cancer, IB & - & 40 & - & 5660 & 32 & 52 & - & 4 \\
\hline 13 & Ovarian cancer, IIA & $\mathrm{HE}+\mathrm{SOE}$ & - & 40 & 1200 & 47 & 50 & Split 1 & 7 \\
\hline 14 & Cervical cancer, IIA & - & 40 & - & 6080 & 45 & 51 & - & 13 \\
\hline 15 & Cervical cancer, IB & - & 40 & - & 5820 & 39 & 44 & - & 7 \\
\hline 16 & Cervical cancer, IB & - & 40 & - & 6840 & 30 & 47 & - & 7 \\
\hline 17 & Ovarian cancer, IC & SOE & - & 40 & 1600 & 56 & 50 & - & 11 \\
\hline 18 & Ovarian cancer, IIB & SOE & - & 36 & 1500 & 57 & $\begin{array}{l}\text { Not } \\
\text { estimated }\end{array}$ & Split 6 & 29 \\
\hline 19 & Ovarian cancer, IIB & SOE & - & 40 & 1440 & 49 & 53 & Split 4 & 20 \\
\hline 20 & Ovarian cancer (granulosa) & $\mathrm{HE}+\mathrm{SOE}$ & - & 40 & 1280 & 40 & 60 & Split 1 & 7 \\
\hline
\end{tabular}




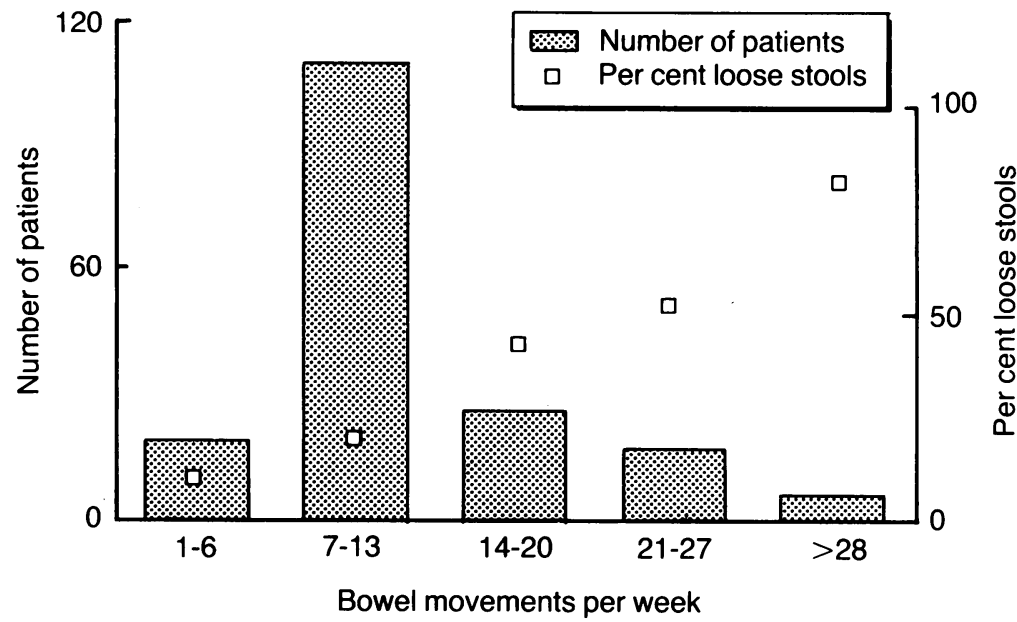

Figure 1: Frequency of bowel movements per week in patients treated for gynaecological cancer $(n=173)$. Percentage of loose stools is indicated with a square.

were expressed as accumulated per cent expired ${ }^{14} \mathrm{CO}_{2}$ of administered cholyl $\left[{ }^{14} \mathrm{C}\right]$-glycine per mmol $\mathrm{CO}_{2}$ at four or six hours. Values above $1 \cdot 5$ and $3.0 \%$ respectively were considered abnormal, indicating bacterial contamination of the small bowel or bile acid malabsorption. Only patients with an abnormal bile acid breath test in combination with a normal SeHCAT were considered to have bacterial contamination of the small bowel.

\section{$\left[{ }^{14} C\right]$-xylose breath test}

After an overnight fast the patient received an oral dose of $5 \mu \mathrm{Ci}(0.2 \mathrm{MBq})$ of $\left[{ }^{14} \mathrm{C}\right]-\mathrm{D}$-xylose (Radiochemical Centre, Amersham, UK) and $1 \mathrm{~g}$ $\mathrm{D}$-xylose dissolved in $250 \mathrm{ml}$ of water. The expired $\mathrm{CO}_{2}$ was trapped using the same system as for the bile acid breath test. Measurements were performed after 30,60 , and 120 minutes. The accumulated value at two hours was calculated as described for the bile acid breath test. An accumulated value at two hours exceeding $3 \cdot 3 \%$ of the given dose was considered abnormal, indicating bacterial contamination of the small intestine. ${ }^{1+}$

\section{Small intestine biopsies}

Biopsy specimens were obtained from 19 patients with a Watson capsule attached to a gastroscope via the biopsy channel and guided into the jejunum at the level of the ligament of Treitz. The biopsy specimen was examined

TABLE II Bowel movements in 173 patients subjected to radiotherapy for gynaecological cancer (numbers are percentages)

\begin{tabular}{|c|c|c|c|c|c|}
\hline & \multicolumn{5}{|c|}{ No of bowel movements per week } \\
\hline & $\begin{array}{l}0 \cdot 6 \\
(n=19)\end{array}$ & $\begin{array}{l}7-13 \\
(n=108)\end{array}$ & $\begin{array}{l}14-20 \\
(n=23)\end{array}$ & $\begin{array}{l}21-28 \\
(n=17)\end{array}$ & $\begin{array}{l}\geq 28 \\
(n=6)\end{array}$ \\
\hline Patients with a cholecystectomy $(n=37)$ & $21(n=4)$ & $19(n=20)$ & $13(n=3)$ & $35(n=6)$ & $67(n=4)$ \\
\hline \multicolumn{6}{|c|}{ Patient's score ${ }^{\star}$} \\
\hline I & 42 & 43 & 0 & 24 & 0 \\
\hline II & 42 & 46 & 61 & 47 & 17 \\
\hline III & 11 & 5 & 22 & 6 & 17 \\
\hline IV & 5 & 6 & 17 & 23 & 67 \\
\hline $\begin{array}{l}\text { Loose stools (proportion of bowel } \\
\text { movements) }\end{array}$ & 16 & 28 & 52 & 76 & 83 \\
\hline \multirow{2}{*}{$\begin{array}{l}\text { Urgency (proportion of bowel } \\
\text { movements) }\end{array}$} & & & & & \\
\hline & 14 & 11 & 31 & 32 & 70 \\
\hline
\end{tabular}

^I=always normal bowel habits, IV = continuously abnormal bowel habit. by conventional light microscopy for villous atrophy, and with scanning electron microscopy for detection of bacteria adherent to the intestinal mucosa. ${ }^{15}$ One biopsy specimen was inadequately fixed and thus not evaluated by the latter method.

\section{Chemical test}

For feacal fat determinations stools were collected for three days after a diet containing a minimum of $100 \mathrm{~g}$ fat per day was taken three days before and during the test. The fat content of the faeces was measured by the method described by van de Kamer et al. ${ }^{16}$ Values above $7 \mathrm{mmol} / \mathrm{day}$ (triglycerides) were considered abnormal. For the xylose absorption test, $25 \mathrm{~g}$ D-xylose in 500 $\mathrm{ml}$ isotonic solution was administered after an overnight fast, urine was collected over the subsequent five hours, and the xylose content determined. ${ }^{17}$ In addition, serum and urine creatinine concentrations were measured to calculate the creatinine clearance, which served as a control for urine collection and renal function. A urinary value below $30 \mathrm{mmol}$ xylose $/ 5 \mathrm{~h}$ was regarded as abnormal.

Vitamin B-12 was measured in serum by radioimmunoassay in 121 patients, according to the local laboratory practice of the hospital. Values below $133 \mathrm{pmol} / \mathrm{l}$ were considered abnormal. Patients included in the group undergoing further gastrointestinal evaluation were also investigated with the Schilling test if they had an abnormal serum vitamin B-12. In the test B-12 with $\left({ }^{57} \mathrm{Co}\right)$ and without intrinsic factor $\left({ }^{58} \mathrm{Co}\right)$ was used and the urine output of B-12 during 24 hours for both isotopes was determined.

The lactose tolerance test was performed after an overnight fast. The patient received $50 \mathrm{~g}$ lactose and blood glucose was determined at 0 , $15,30,60,90$, and 120 minutes. An increment in blood glucose under $2.2 \mathrm{mmol} / \mathrm{l}$ was considered abnormal. In order to increase the sensitivity and specificity the test was repeated with a mixture of $25 \mathrm{~g}$ glucose and $25 \mathrm{~g}$ galactose as substrates. If the increment in blood glucose was also subnormal with this test the lactose tolerance test was considered false positive - that is, not due to lactase deficiency but to general malabsorption or slow gastric emptying.

\section{TREATMENT}

All patients were treated with a combination of metronidazole $400 \mathrm{mg}$ three times daily and doxycycline $100 \mathrm{mg}$ daily for 7-10 days, before the results of their bile acid and ${ }^{14} \mathrm{C}$-xylose breath tests were known. The breath tests were repeated in all patients after completing treatment. The patients recorded daily their symptoms and the number of stools on a diary card one week before and during antibiotic treatment.

Patients with a very low SeHCAT value (WBR-50<40 h), indicating severe bile acid malabsorption, were treated with a bile acid sequestrant (cholestyramine 4-8 g daily) and a reduced fat diet after antibiotic treatment. Patients with abnormal bile acid and xylose breath tests, indicating bacterial contamination, 

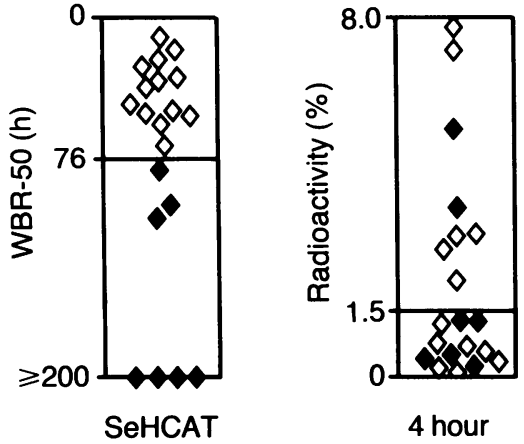

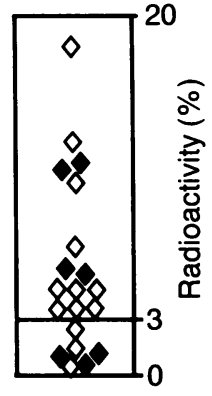

6 hour
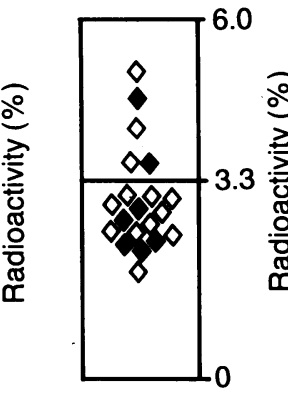

${ }^{14} \mathrm{C}-\mathrm{xy}$ lose breath test
Bile acid breath tests
Figure 2: Outcome of bile acid and ${ }^{14} \mathrm{C}$-xylose breath tests and ${ }^{75}$ Selenahomocholic acid-taurine test (SeHCAT). Open symbols indicate patients with abnormal SeHCAT. The results of the breath tests are expressed as accumulated radioactivity in per cent of given dose. The lower reference value for normal controls $+2 S D$ is indicated by a horizontal line. $W B R-50=$ biological half life of the isotope. having fewer $\left(\chi^{2}=6 \cdot 26 ; \mathrm{p}<0 \cdot 02\right.$, Table II). Of the 173 patients, 121 were tested for vitam B-12 deficiency and 15 had low values $(12 \%)$.

The group subject to further gastrointestinal evaluation did not differ significantly from the entire population with severe diarrhoea with regard to age at treatment (mean 45 years, range 26-68), time from radiotherapy (mean 11 years, range 4-29), type of cancer, or accumulated dose (mean 45 Gy, range 30-60). The radiation cards completed at the time of treatment indicated that they had all had diarrhoea during radiotherapy: eight severe and 12 from mild to moderate. Interruption of radiotherapy because of diarrhoea was necessary in nine cases and Table I gives details of such split treatment. In one case (patient 9) the diarrhoea was so severe that treatment was discontinued at $36 \mathrm{~Gy}$.

\section{SEHCAT}

Thirteen of the 20 patients $(65 \%)$ investigated extensively had reduced SeHCAT values according to the local reference value of 76 hours, and seven had values below 40 hours which in our experience is consistent with pronounced bile acid malabsorption and choleretic diarrhoea (Fig 2). Seven of $10(70 \%)$ patients who had had a cholecystectomy had low SeHCAT values (Table III). There was no correlation between the SeHCAT value and bowel frequency.

\section{STATISTICS}

Correlations were analysed with Spearman's correlation test, and differences between groups with the $\chi^{2}$ test with Yeats's correction for small numbers or by Fisher's exact probability test when appropriate. Differences within groups were analysed with Wilcoxon's signed rank test.

\section{Results}

\section{BOWEL HABIT}

There was no relation between the different cancers treated with radiotherapy and the development of diarrhoea. Furthermore, there was no significant difference between the groups with diarrhoea ( $\geq 21$ bowel movements per week) and without diarrhoea with respect to type of cancer, age at treatment (mean 50 and 44 years respectively), interval between treatment and evaluation (mean 9 and 11 years respectively), or calculated radiation dose to the rectum (mean 42 and $43 \mathrm{~Gy}$ respectively). Figure 1 shows that the proportion of loose stools increased with the frequency of bowel movements. Table II shows the results of the questionnaire regarding the frequency of defecation, and cholecystectomy, the frequency of urgency and loose stools, and the patient's scoring of her bowel habit. Twenty three patients $(13 \%)$ reported 21 or more bowel movements a week and six patients $(3 \%) 28$ or more, among them one patient with 51 a week. As the frequency of bowel movements increased, so the proportion of loose stools increased from 16 to $83 \%$ and the proportion of urgent bowel movements from 14 to $70 \%$. The patients' scoring showed an increasing feeling of discontent. Significantly more patients with a cholecystectomy were among the patients having 21 or more bowel movements a week than among those

\section{BREATH TESTS}

The results of the breath tests are summarised in Figure 2. Four patients (20\%) had abnormal six hour bile acid breath tests with a normal SeHCAT, which is consistent with bacterial contamination of the small bowel. In addition, five patients $(25 \%)$ had an abnormal ${ }^{14} \mathrm{C}$-xylose breath test, indicating bacterial contamination of the small bowel. Three of these also had tant bile acid malabsorption and bacterial contamination.

There was no correlation between the two results of the breath tests (Fig 3). On the contrary, there was a negative but not significant correlation between the two test, irrespective of the outcome of the SeHCAT test.

Only two patients had abnormal results in

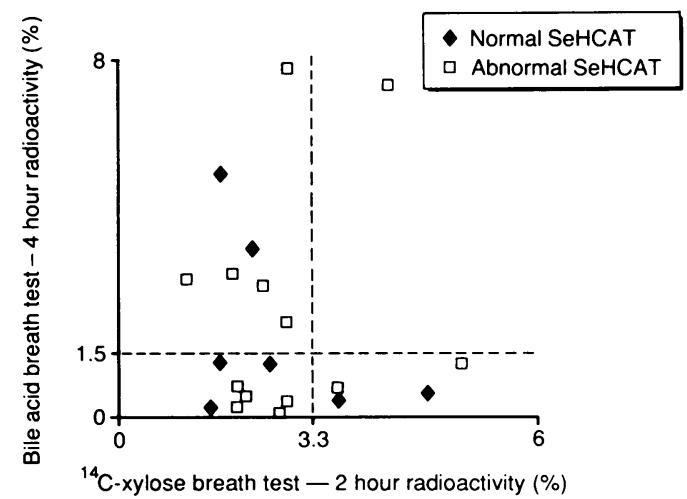

Figure 3: Four hour bile acid breath test plotted against ${ }^{1+} \mathrm{C}$ xylose breath test. The values represent accumulated radioactivity in per cent of given dose. The reference value for normal controls $+2 S D$ is indicated by broken lines. abnormal SeHCAT values, indicating concomi- 
TABLE III Malabsorption and breath tests, ScHCAT, scanning electron microscopy, and operations not related to cancer treatment in patients with chronic diarrhoea after radiation treatment for gynaecological cancer

\begin{tabular}{|c|c|c|c|c|c|c|c|c|}
\hline \multirow{2}{*}{$\begin{array}{l}\text { Patient } \\
\text { No }\end{array}$} & \multirow{2}{*}{$\begin{array}{l}\text { Fat in faeces } \\
\text { (mmol/day) }\end{array}$} & \multirow{2}{*}{$\begin{array}{l}\text { Xylose test } \\
(\mathrm{mmol} / 5 \mathrm{~h})\end{array}$} & \multirow{2}{*}{$\begin{array}{l}\text { SeHCAT } \\
(W B R-50 h)\end{array}$} & \multicolumn{2}{|c|}{ Bile acid breath test $(\%)$} & \multirow{2}{*}{$\begin{array}{l}2 \text { hour } \\
{ }^{1+} C-x y l o s e \\
\text { breath test } \\
(\%)\end{array}$} & \multirow{2}{*}{$\begin{array}{l}\text { Scanning } \\
\text { electron } \\
\text { microscopy } \\
\text { (bacteria) }\end{array}$} & \multirow[b]{2}{*}{ Operations } \\
\hline & & & & 4 hour & 6 hour $^{\circ}$ & & & \\
\hline 1 & $9 \cdot 5^{\star}$ & 47 & $32^{\star}$ & $0 \cdot 4$ & $3 \cdot 8^{\star}$ & $3 \cdot 0$ & Short rods & \multirow[t]{2}{*}{ Cholecystectomy } \\
\hline 2 & $6 \cdot 2$ & $30^{\star}$ & $>200$ & 0.5 & $1 \cdot 0$ & $4 \cdot 7^{\star}$ & - & \\
\hline 3 & $6 \cdot 4$ & 43 & $>200$ & $1 \cdot 2$ & $5 \cdot 7^{\star}$ & $2 \cdot 8$ & - & \multirow[b]{2}{*}{ Cholecystectomy } \\
\hline 4 & $13 \cdot 7^{\star}$ & 34 & $21^{\star}$ & 0.2 & $3 \cdot 7^{\star}$ & $2 \cdot 4$ & & \\
\hline 5 & $10 \cdot 7^{\star}$ & $25^{\star}$ & $24^{\star}$ & $3 \cdot 1^{\star}$ & $4 \cdot 7^{\star}$ & 1.8 & Not done & \multirow[b]{2}{*}{ Cholecystectomy } \\
\hline 6 & $5 \cdot 2$ & $26^{\star}$ & 102 & $3 \cdot 2^{\star}$ & $11 \cdot 9 \star$ & $2 \cdot 6$ & Short rods & \\
\hline 7 & $15 \cdot 6^{\star}$ & $21^{\star}$ & $37^{\star}$ & $7 \cdot 8^{\star}$ & $18 \cdot 3^{\star}$ & $3 \cdot 0$ & - & \multirow[b]{2}{*}{ Cholecystectomy } \\
\hline 8 & $9 \cdot 7^{\star}$ & 39 & 109 & $5 \cdot 5^{\star}$ & $11 \cdot 4^{\star}$ & $2 \cdot 2$ & - & \\
\hline 9 & $7 \cdot 4^{\star}$ & 40 & $47^{\star}$ & $1 \cdot 2$ & $3 \cdot 6^{\star}$ & $5 \cdot 1^{\star}$ & - & Explorative laparotomy \\
\hline 10 & $9 \cdot 6^{\star}$ & Not done & $51^{\star}$ & $0 \cdot 1$ & $0 \cdot 2$ & $2 \cdot 9$ & - & \multirow[b]{2}{*}{$\begin{array}{l}\text { Cholecystectomy } \\
\text { Billroth II partial gastrectomy }\end{array}$} \\
\hline 11 & $14 \cdot 9^{\star}$ & $17^{\star}$ & $\cdot 32^{\star}$ & $7 \cdot 4^{\star}$ & $13 \cdot 1^{\star}$ & $4 \cdot 2^{\star}$ & $\begin{array}{l}\text { Not } \\
\text { evaluated }\end{array}$ & \\
\hline 12 & $5 \cdot 5$ & $19^{\star}$ & $>200$ & $0 \cdot 2$ & $0 \cdot 4$ & $2 \cdot 1$ & $\overline{-}$ & \multirow{4}{*}{$\begin{array}{l}\text { Cholecystectomy } \\
\text { Cholecystectomy }\end{array}$} \\
\hline 13 & $5 \cdot 5$ & Not done & $53^{\star}$ & 0.7 & $4 \cdot 7^{\star}$ & $2 \cdot 4$ & Short rods & \\
\hline 14 & $3 \cdot 6$ & 31 & $52^{\star}$ & 0.5 & $1 \cdot 5$ & $2 \cdot 5$ & Long rods & \\
\hline 15 & $7 \cdot 5^{\star}$ & 37 & $>200$ & $0 \cdot 4$ & 0.9 & $3 \cdot 6^{\star}$ & $\bar{x}$ & \\
\hline 16 & $6 \cdot 6$ & 39 & $12^{\star}$ & 0.7 & $2 \cdot 7$ & $3 \cdot 6^{\star}$ & Long rods & $\begin{array}{l}\text { Cholecystectomy } \\
\text { Extrauterine pregnancy }\end{array}$ \\
\hline 17 & $2 \cdot 0$ & 34 & $56^{\star}$ & $3 \cdot 0^{\star}$ & $4 \cdot 8^{\star}$ & $2 \cdot 7$ & - & \\
\hline 18 & $21 \cdot 2^{\star}$ & 41 & $67^{\star}$ & $3 \cdot 3^{\star}$ & $7 \cdot 2^{\star}$ & $2 \cdot 3$ & Short rods & \\
\hline 19 & $2 \cdot 2$ & $18^{\star}$ & $17^{\star}$ & $2 \cdot 2^{\star}$ & $10^{\cdot 9 \star}$ & $3 \cdot 0$ & - & Cholecystectomy \\
\hline 20 & 1.9 & 54 & 83 & $1 \cdot 3$ & $5 \cdot 8^{\star}$ & $2 \cdot 2$ & Long rods & Cholecystectomy \\
\hline
\end{tabular}

^Abnormal value. WBR-50=biological half life of the isotope.

both breath tests, but both had low SeHCAT values which makes the bile acid breath test unreliable for detection of small intestinal bacterial overgrowth (patients 9 and 11, Table III).

SCANNING ELECTRON MICROSCOPY

Seven of 18 patients (39\%) investigated with scanning electron microscopy had adherent bacteria on the small intestinal biopsy specimens (Table III). There was no correlation between the outcome of the breath tests and of this investigation. It is notable, however, that a high proportion (6 of $10,67 \%$ ) of patients who had had a cholecystectomy had adherent bacteria on the mucosa of the small intestine compared with only one of the other patients $(\mathrm{p}<0.05)$. No patient had villous atrophy or severe inflammatory changes of the small intestinal epithelium as judged by light microscopic examination.

MALABSORPTION TESTS

Among the 20 patients further investigated, six patients had a low serum B-12 $(30 \%)$ and one patient was on substitution treatment (Table

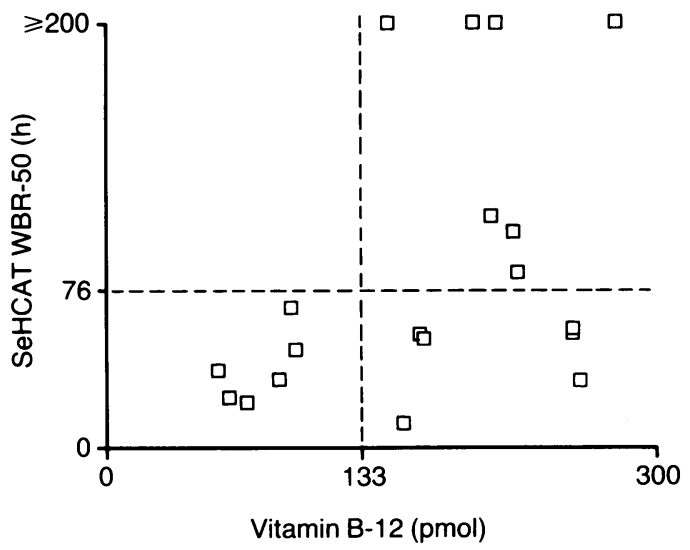

Figure 4: Serum B-12 plotted against the outcome of the SeHCAT test. The lower reference values for normal controls are indicated by broken lines. $W B R-50=$ biological half life of the isotope.
IV). There was a weak but significant correlation between serum B-12 and SeHCAT $\left(r_{s}=0.46\right.$; $\mathrm{p}<0.05$, Fig 4) and no patient with a low B-12 value had a normal SeHCAT. The Schilling test was normal in all but one patient. A high ratio was found for one of the patients (patient 7 , Table IV).

Ten patients $(50 \%)$ had an abnormally high faecal fat excretion and seven patients $(35 \%)$ an abnormal xylose absorption test (Table III). Faecal fat excretion tended to be higher in the patients with reduced SeHCAT values, but was normal in the two patients with the lowest SeHCAT value. Only three of the seven patients with abnormal xylose absorption tests had breath tests indicating bacterial contamination of the small bowel. Two were identified with the ${ }^{14} \mathrm{C}$ xylose breath test and one with the bile acid breath test. Of the remaining four patients, three had low SeHCAT values ( $<40$ hours) and in one the low xylose test was the only abnormality

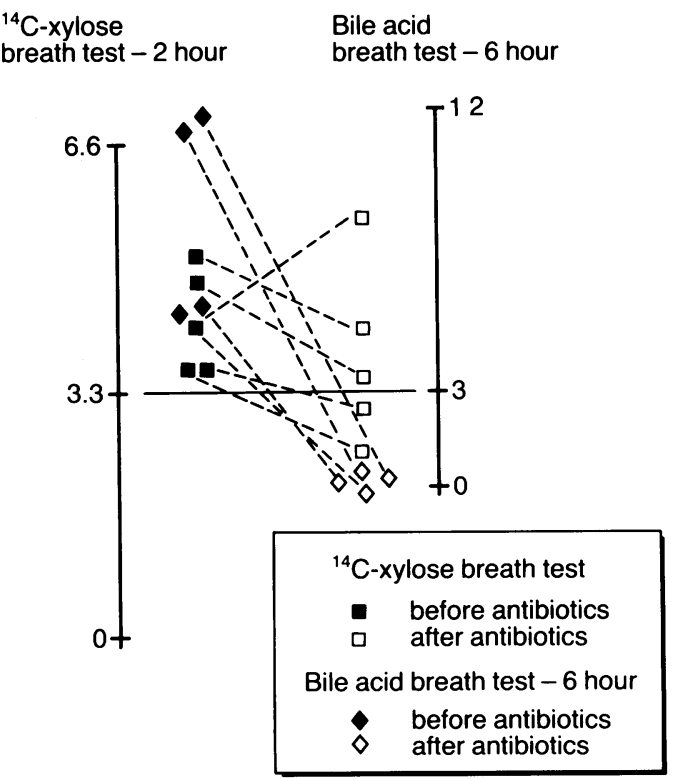

Figure 5: Six hour bile acid and two hour ${ }^{14} C$-xylose breath tests before and after treatment with antibiotics. 
Figure 6: Bowel movements per week for 20 patients before and after treatment recorded on diary cards. The numbers represent the patients. Patients are grouped according to the outcome of the investigations.

Miscellaneous indicates patients with lactose malabsorption (patient 17), slightly abnormal SeHCAT $(76 \mathrm{~h}>$ half life $>40 \mathrm{~h}$, patients 10,13,14, and 18) and one patient with no abnormality detected (patient 12). Connecting lines are drawn for each patient. Dotted lines indicate incomplete evaluations. WBR-50 = biological half life of the isotope.

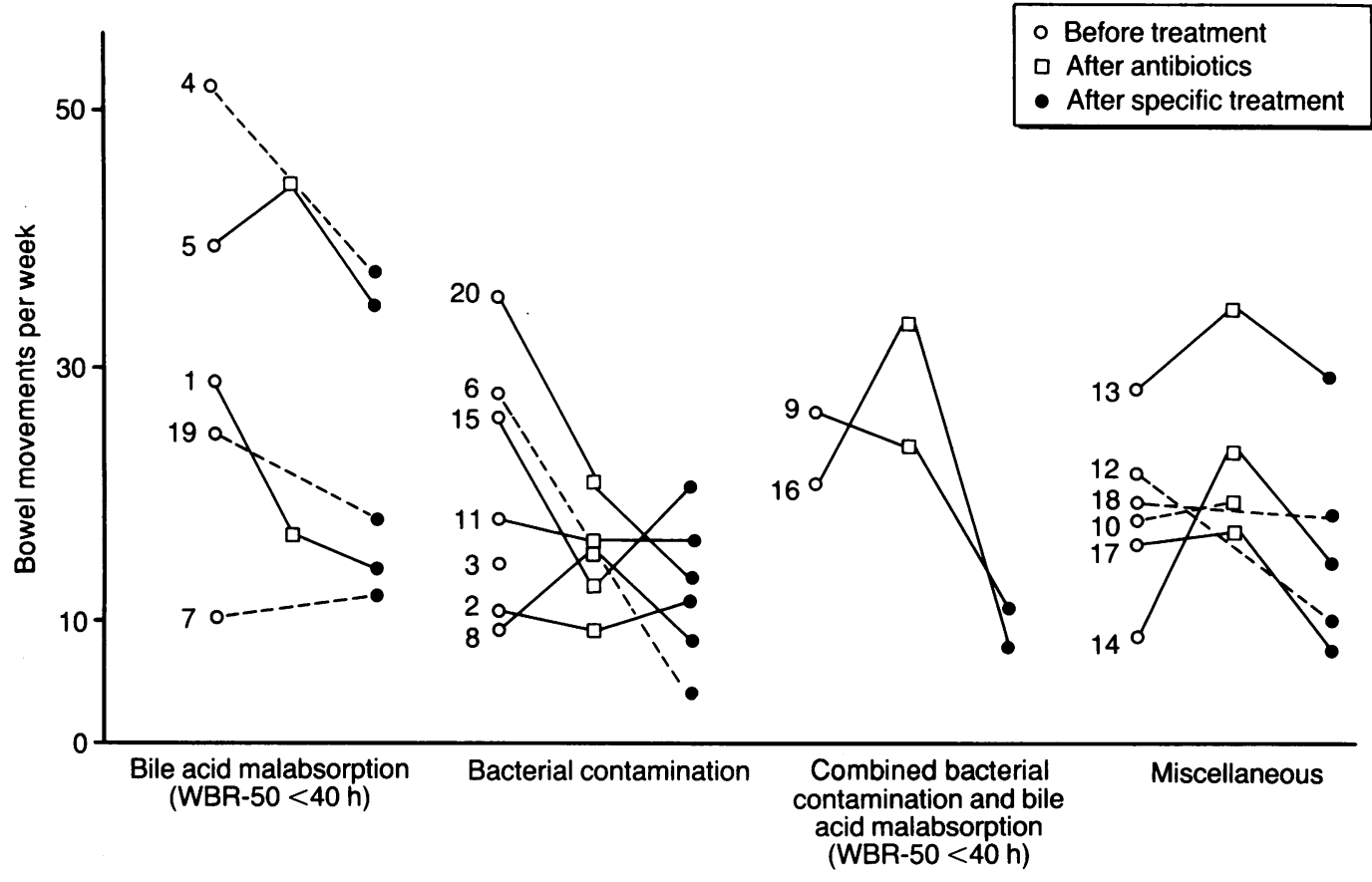

detected. Only one patient had a clearly abnormal lactose tolerance test in combination with a normal glucose-galactose test (Table IV).

\section{RESPONSE TO TREATMENT}

The effect of antibiotic treatment on the two breath tests is shown in Figure 5, where there was a significant reduction $(\mathrm{p}<0.05)$, though the result was less pronounced for the ${ }^{14} \mathrm{C}$-xylose test than for the bile acid test. The effects of the various treatments on the diarrhoea are shown in Figure 6. Thirteen patients $(65 \%)$ were evaluated during antibiotic treatment, and $18(90 \%)$ were reevaluated two years later after being treated with specific regimens according to the outcome of the investigations. One patient was lost to follow up and one died (patient 10). The responses are shown in Figure 6, where each patient is placed in her diagnostic group. Of the nine patients with signs of bacterial contamination of the small bowel, suggested either by an abnormal bile acid breath test in combination with a normal SeHCAT or an abnormal ${ }^{14} \mathrm{C}$ xylose breath test, the diarrhoea of three responded well to antibiotics, whereas that in the remaining patients worsened or was unchanged. Although in most of the seven patients with pronounced bile acid malabsorption (WBR-50 $<40 \mathrm{~h}$ ) symptoms improved during treatment with a bile acid sequestrant and a reduced fat diet, the overall effect was moderate. The two patients with both abnormal ${ }^{14} \mathrm{C}$-xylose breath tests and SeHCAT tests (WBR-50 $<40 \mathrm{~h}$ ), indicating bacterial contamination and bile acid malabsorption, did not improve after initial treatment with antibiotics but substantially improved after the addition of a bile acid sequestrant and a reduced fat diet (Fig 6). Bowel frequency was decreased significantly $(p<0.01)$ by the specific treatment.

\section{Discussion}

The results of this investigation suggest that chronic diarrhoea after radiotherapy for gynaecological cancer is common and sometimes disabling. Of the 173 patients studied, 13\% reported 21 or more bowel movements a week and of these, $43 \%$ were discontent with their bowel habit for most of the time.

Patients with gastrointestinal complaints, however, are usually seen more frequently than those without and followed up for a longer time, and the survival rate for cervical cancer is higher than for ovarian carcinomas. Thus a selection bias leading to an excess of patients treated for cervical carcinoma with gastrointestinal complications was inevitable and must be taken into account when interpreting the results.

There was no relation between the patient's age, the estimated rectal dose, location of the cancer, and development of chronic or intermittent diarrhoea. The radiation technique and the dose on the pelvic organs vary considerably, ${ }^{18} 1$ and the exposure of the small intestine is also influenced by the position and mobility of the other important factors are anatomical differences and body composition, as well as previous pelvic infections and abdominal surgery. ${ }^{20}$

Vitamin B-12 deficiency was found in 13\% of the patients tested, which is in accordance with figures reported by Lantz and Einhorn ${ }^{21}$ and supports the recommendation of regular B-12 surveillance in this group of patients. Among the 20 patients subject to extended gastrointestinal investigation, the frequency of B-12 deficiency was even higher (30\%). A normal Schilling test result was found in all but one patient in contrast to the results obtained by $\mathrm{McBrien}^{22}$ in patients who had received cobalt teletherapy for carcinoma of the bladder, but supports the observations of Holdstock et $a l^{23}$ of a low serum B-12 and a normal Schilling test in patients with Crohn's disease of the terminal ileum. In the present study all patients with low serum B-12 values had abnormally low SeHCAT values, and a correlation between serum B-12 and SeHCAT small intestine, notably the ileum. In addition, 
TABLE IV Outcome of lactose absorption tests, serum B-12, and Schilling tests

\begin{tabular}{|c|c|c|c|c|c|c|}
\hline \multirow[b]{2}{*}{$\begin{array}{l}\text { Patient } \\
\text { No }\end{array}$} & \multirow[b]{2}{*}{$\begin{array}{l}\text { Lactose } \Delta \\
P \text {-glucose } \\
\text { (mmolll) }\end{array}$} & \multirow[b]{2}{*}{$\begin{array}{l}\text { Glucosel } \\
\text { galactose } \Delta \\
P \text {-glucose } \\
\text { (mmolll) }\end{array}$} & \multirow[b]{2}{*}{$\begin{array}{l}\text { Serum B-12 } \\
(p m o l l l)\end{array}$} & \multicolumn{3}{|c|}{ Schilling test (pmolll) } \\
\hline & & & & $\begin{array}{l}\text { With } \\
\text { intrinsic } \\
\text { factor }\end{array}$ & $\begin{array}{l}\text { Without } \\
\text { intrinsic } \\
\text { factor }\end{array}$ & $\begin{array}{l}\text { Ratio } \\
\text { with/ } \\
\text { without }\end{array}$ \\
\hline \multirow{18}{*}{$\begin{array}{r}1 \\
2 \\
3 \\
4 \\
5 \\
6 \\
7 \\
8 \\
9 \\
10 \\
11 \\
12 \\
13 \\
14 \\
15 \\
16 \\
17 \\
18 \\
19 \\
20\end{array}$} & $\begin{array}{l}5 \cdot 6 \\
2 \cdot 5\end{array}$ & $\begin{array}{l}\text { Not done } \\
2 \cdot 7\end{array}$ & $\begin{array}{l}259 \\
200\end{array}$ & & & \\
\hline & $1 \cdot 9 \star$ & Not done & 213 & & & \\
\hline & $2 \cdot 2$ & $2 \cdot 4$ & $74^{\star}$ & $10 \cdot 3$ & $11 \cdot 4$ & 0.9 \\
\hline & $3 \cdot 0$ & $2 \cdot 6$ & $65^{\star}$ & $6 \cdot 6^{\star}$ & $6 \cdot 1^{\star}$ & $1 \cdot 1$ \\
\hline & $4 \cdot 1$ & $3 \cdot 7$ & 223 & & & \\
\hline & $2 \cdot 5$ & $2 \cdot 9$ & $60^{\star}$ & $22 \cdot 6$ & $10 \cdot 0$ & $2 \cdot 3$ \\
\hline & $3 \cdot 3$ & $3 \cdot 1$ & 210 & & & \\
\hline & $2 \cdot 7$ & $3 \cdot 4$ & $102^{\star}$ & $15 \cdot 9$ & $11 \cdot 2$ & $1 \cdot 4$ \\
\hline & $6 \cdot 7$ & $6 \cdot 7$ & 173 & & & \\
\hline & $3 \cdot 7$ & Not done & $93^{\star}$ & $10 \cdot 4$ & $10 \cdot 6$ & $1 \cdot 0$ \\
\hline & $4 \cdot 8$ & Not done & 153 & & & \\
\hline & $\begin{array}{l}2 \cdot 5 \\
2 \cdot 8\end{array}$ & $\begin{array}{l}2 \cdot 3 \\
2 \cdot 4\end{array}$ & $\begin{array}{l}170 \\
254\end{array}$ & & & \\
\hline & $0.9 \star$ & $\begin{array}{l}2 \cdot 4 \\
1 \cdot 3^{\star}\end{array}$ & $\begin{array}{l}234 \\
278\end{array}$ & & & \\
\hline & 3.9 & 3.9 & 167 & & & \\
\hline & $1 \cdot 3^{\star}$ & $4 \cdot 6$ & 254 & & & \\
\hline & $4 \cdot 5$ & Not done & $100^{\star}$ & $11 \cdot 8$ & $12 \cdot 0$ & $1 \cdot 0$ \\
\hline & $2 \cdot 3$ & $2 \cdot 2$ & Substituted & & & \\
\hline & 4.9 & $3 \cdot 5$ & 226 & & & \\
\hline
\end{tabular}

$\star$ Abnormal value. disturbed motility was at least partly responsible for the finding.

Bacterial cultures and indirect tests such as the bile acid breath test and ${ }^{14} \mathrm{C}$-xylose breath test are usually used to diagnose bacterial contamination of the small bowel. Evidence of bacterial contamination was found in nine $(45 \%)$ of the patients tested using the breath tests in combination with the SeHCAT. By combining the bile acid breath test with the SeHCAT the specificity of the bile acid test will increase with respect to the diagnosis of bacterial contamination, as SeHCAT identifies only patients with bile acid malabsorption. ${ }^{26}$ Furthermore, using both breath tests increases the probability of finding bacterial overgrowth since the bile acid breath test is sensitive to anaerobic bacteria, especially bacteroides, whereas the ${ }^{14} \mathrm{C}$-xylose test is better at identifying Gram positive aerobic bacteria. ${ }^{12} 27$ The breath tests merely provide indirect evidence of bacterial contamination, and most of the tests have been found to have a relatively low sensitivity. ${ }^{28}$ The ${ }^{14} \mathrm{C}$-xylose test has been claimed to be superior to other breath tests for both sensitivity and specificity. ${ }^{29}$ Recent studies, however, have not confirmed this claim, ${ }^{1+30}$ and the lack of correlation between the two tests in the present investigation further suggests that no single breath test is sufficient for diagnosing small intestinal bacterial overgrowth.

Adherent bacteria were found by scanning electron microscopy in $39 \%$ of the patients. In a recent investigation bacteria were found in approximately $10 \%$ of unselected small intestinal biopsy specimens, ${ }^{15}$ and $36 \%$ of specimens from patients with chronic or intermittent diarrhoea. The presence of adherent bacteria on the small intestinal mucosa did not correlate with the outcome of the breath tests, ${ }^{14}$ which was also the case in the present study. Most of the patients $(67 \%)$ with bacterial adhesion in this study had had a cholecystectomy, thus pointing to a possible relation between altered bile acid secretion and the presence of adherent bacteria.

Even though a high frequency of bile acid and fat malabsorption was found in our patients, a reduced fat diet and treatment with a bile acid sequestrant had only a moderate effect on the diarrhoea. Sphincter dysfunction is another possible explanation for the increased frequency of bowel movements and urgency found in the present investigation. Radiotherapy for prostatic cancer has been shown to affect the internal anal sphincter causing urgency, an increased frequency of defecation, and even incontinence. ${ }^{31}$ Our patients received a radiation dose to the rectum of $30-60 \mathrm{~Gy}$, which is comparable to the dose of 50 Gy given for prostatic cancer. ${ }^{31}$ In other investigations cholestyramine has been shown to favourably affect acute diarrhoea during radiotherapy, and good results have also been reported for occasional patients with chronic diarrhoea induced by radiotherapy. ${ }^{32-34}$ Bile acid sequestrants should be used with caution, since an increase in pre-existing fat malabsorption may be induced and thereby worsen the diarrhoea. ${ }^{35}$ To avoid this a colon release capsule with cholestyramine has been suggested for patients with severe fat and bile acid malabsorption. ${ }^{36}$
Small intestinal strictures or altered motility, or both, giving rise to a functional stagnant loop and bacterial overgrowth, can also lead to chronic diarrhoea. It has been reported by Dalla Palma $^{25}$ that B-12 malabsorption occurs during radiotherapy even if the terminal ileum is not in the irradiation field, and it was suggested that 
Five of nine patients (55\%) with bacterial contamination of the small intestine, including two patients with concomitant bile acid malabsorption were improved by treatment with antibiotics or antibiotics and bile acid sequestrants, a response rate similar to that in a previous report. ${ }^{30}$

Lactose malabsorption was found only in one patient, which is less than expected when compared to a previous report ${ }^{37}$ on acute radiation enteritis. The difference between the present and the previous study is probably due to the differences between the patients and to the prevalence of lactose malabsorption in the populations $(5-19 \% v<5 \%$ in Sweden).

From the present study it can be concluded that bile acid malabsorption and bacterial overgrowth are frequently found in patients with chronic or intermittent diarrhoea after radiotherapy for gynaecological cancer. There seems to be an association between the development of diarrhoea and cholecystectomy. B-12 deficiency is often found in this group of patients and the deficiency seems to correlate with bile acid malabsorption. Both are probably due to a radiation induced dysfunction of the terminal ileum. The combination of bile acid breath test and SeHCAT together with the ${ }^{14} \mathrm{C}$-xylose breath test is useful in evaluating patients with chronic diarrhoea after radiotherapy since both bile acid malabsorption and bacterial contamination by anaerobic and aerobic bacterias can be detected. Guided by the results of the gastrointestinal investigations, treatment with bile acid sequestrants, a reduced fat diet, and antibiotics can be tried.

This work was supported by the Lions Research Foundation and by the Medical Faculty, University of Umeå, Sweden. The authors are indebted to Mrs Ingegerd Söderström for skilled technical assistance.

1 Rubin P, Casarett G. A direction for clinical radiation pathology: the tolerance dose. In: Vaeth JM, ed. Frontiers of radiation therapy and oncology. Baltimore: University Park Press, 1972: 1-16.

2 Warren S, Friedman NB. Pathology and pathologic diagnosis of radiation lesions in the gastrointestinal tract. Am $\mathcal{F}$ Patho 1942; 18: 499-513.

3 Galland RB, Spencer J. Natural history and surgical management of radiation enteritis. Br 7 Surg 1987; 74: 742-7.

4 Anderon $\mathrm{H}$, Bosaeus I, Nyström C. Bile salt malabsorption in the radiation syndrome. Acta Radiol 1978; 17: 312-8.

5 Kinsella TJ, Bloomer WD. Tolerance of the intestine to radiation therapy. Surg Gynecol Obstet 1980; 151: 273-84.

6 Newman A, Katsaris J, Blendis LM, Charlesworth M, Walter LH. Small intestinal injury in women who have had pelvic LH. Small intestinal injury in women

7 Conklin JL Anuras S. Radiation-induced recurrent intestinal pseudo-obstruction. Am 7 Gastroenterol 1981; 75: 440-4.

$8 \mathrm{Kottmeier} \mathrm{HL}$. Surgical and radiation treatment of invasive carcinoma of the uterine cervix. Experience by curren individualized Stockholm technique. Acta Obstet Gynecol Scand 1964; 43 (suppl 2): 1-48.

9 Kjellgren, Jonsson L Further development of the Heyman packing method. Acta Radiol 1965; 2: 143-51.

10 Nyhlin H, Brydon G, Danielsson Â, Westman S. Clinica application of a selenium $\left({ }^{75} \mathrm{Se}\right)$-labelled bile acid for the investigation of terminal

11 enterology $1984 ; 31$ : $187-91$. malabsorption demonstrated by SeHCAT in chronic diarrhoea, with special reference to the impact of cholecystectomy. Scand F Gastroenterol 1988; 23: 1187-94.
12 Fromm H, Hofmann AF. Breath test for altered bile-acid metabolism. Lancet 1971 ; i: $621-5$.

13 Sherr HP, Sasaki Y, Newman A, Banwaell JG, Wagner HN, Hendrix TR. Detection of bacterial deconjugation of bile salts by a convenient breath analysis technic. N Engl f Med 1971; 285: 347-55

4 Suhr O, Danielsson A, Hörstedt P, Stenling R. Bacterial contamination of the small bowel evaluated by breath tests, ${ }^{75} \mathrm{Se}$-labelled homocholic-tauro acid, and scanning electron microscopy. Scand F Gastroenterol 1990; 25: 841-52.

15 Hörstedt $\mathrm{P}$, Danielsson $\AA$, Nyhlin H, Stenling R, Suhr O. Adhesion of bacteria to the human small-intestinal mucosa. A scanning electron microscopic study. Scand $\mathcal{f}$ Gastroenterol 1989; 24: 877-85.

16 van de Kamer JH, Huinink B, Ten B, Weyers HA. Rapid method for the determination of fat in feces. 7 Biol Chem $1949 ; 177: 347-55$

17 Roe JH, Rice EW. A photometric method for the determination of free pentoses in animal tissue. $\mathcal{F}$ Biol Chem 1947; 173: 507-12.

18 Joelsson I, Backström A, Diehl J, Lagergren C. Dose distribution from intracavitary radium and supplementary external irradiation with regard to topography of lymph nodes in carcinoma of the uterine cervix. Acta Radiol 1970; 9: 33-53.

19 Stendahl U, Willén $R$, Willén $H$. Invasive squamous cell carcinoma of the uterine cervix III. A malignancy grading system for indication of prognosis after radiation therapy. Acta Radiol 1981; 20: 231-43.

20 Loludice T, Baxter D, Balint J. Effects of abdominal surgery on the development of radiation enteropathy. Gastroenterology 1977; 73: 1093-7.

21 Lantz B, Einhorn N. Intestinal damage and malabsorption after treatment for cervical carcinoma. Acta Radiol $1984 ; 23$ : 33-6.

22 McBrien MP. Vitamin B12 malabsorption after cobalt teletherapy for carcinoma of the bladder. $B M \mathcal{F} 1973$; i: $648-50$.

23 Holdstock G, Phillips G, Hames TK, et al. Potential of SeHCAT retention as an indicator of terminal ileal involvement in inflammatory bowel disease. Eur 7 Nucl Med 1985 10: $528-30$.

24 Yeoh EK, Lui D, Lee NY. The mechanism of diarrhoea resulting from pelvic and abdominal radiotherapy; a prospective study using selenium-75 labelled conjugated bile acid and cobolt- 58

25 Dalla Palma L. Intestinal malabsorption in patients undergoing abdominal radiation therapy. In: Gastrointestinal radiation injury. Washington DC: Excerpta Medica Foundation, 1968: 261-72.

26 Zentler-Monroe PL, Bessel EM. Medical management of radiation enteritis - an algorithmic guide. Clin Radiol 1987; 38: $291-4$.

27 King CE, Toskes PP, Spivey JC, Lorenz E, Welkos S Detection of small intestinal bacterial overgrowth by means Detection of small intestinal bacterial overgrowth by means 82 .

28 King CE, Toskes PP. The use of breath tests in the study of malabsorption. In: Sleisenger MH, ed. Clinics in gastroenterology London: WB Saunders, 1983: 591-610.

29 King CE, Toskes PP. Comparison of the 1-gram (14C)Xylose 10-gram Lactulose-H2, and the 80-gram Glucose-H2 breath tests in patients with small intestine bacterial overgrowth. Gastroenterology 1986; 91: 1447-51.

30 Rumessen JJ, Gudman-Høyer E, Bachmann E, Justesen T. Diagnosis of bacterial overgrowth of the small intestine. Comparison of the 14-C-D-xylose breath test and jejunal cultures in 60 patients. Scand f Gastroenterol 1985; 20: 1267 75 .

31 Varma JS, Smith AN, Busuttil A. Function of the ana sphincters after chronic radiation injury. Gut 1986; 27 : 528 sphi.

32 Chary S, Thomson DH. A clinical trial evaluating cholestyramine to prevent diarrhoea in patients maintained on low-fat diets during pelvic radiation therapy. Int $\mathcal{F}$ Radiat Oncol Bio Phys 1984; 10: 1885-90.

33 Husinkveld RS, Manning MR, Aristizabal SA. Control of radiation-induced diarrhea with cholestyramine. Int $f$ Radiat Oncol Biol Phys 1978; 4: 687-90.

34 Ludgate SM, Merrick M. The pathogenesis of post-irradiation chronic diarrhoea: Measurement of SeHCAT and $B_{12}$ absorption for differential diagnosis determines treatment. Clin Radiol 1985; 36: 275-8.

35 Hofmann AF, Poley JR. Role of bile acid malabsorption in pathogenesis of diarrhoea and steatorrhea in patients with ileal resection. I. Response to cholestyramine or replacement of dietary long chain triglyceride by medium chain ment of dietary long chain trigleride. Gastroenterology 1972; 62: 918-34.

36 Poley JR, Hofmann AF. Role of fat maldigestion in pathogenesis of steatorrhea in ileal resection. Gastroenterology genesis of steat

37 Stryker JA, Mortel R, Hepner GW. The effect of pelvic irrediation on lactose absorption. Int 7 Radiat Oncol Biol Phys 1978; 4: 859-63. 